\title{
Ecomorphology and resource use by dominant species of tropical estuarine juvenile fishes
}

\author{
André Luiz Machado Pessanha1, Francisco Gerson Araújo², Ronnie Enderson M. C. C. \\ Oliveira$^{1}$, Adna Ferreira da Silva ${ }^{1}$ and Natalice Santos Sales ${ }^{1}$
}

Eleven ecomorphological attributes and diet of seventeen juvenile fish species were examined to test the hypothesis that morphological patterns determine resource uses in estuarine habitats. Species were separated according to the apparatus to food capture and habitat use (benthic or pelagic) in three different groups: (1) a group with depressed fish body, strong caudal peduncle and enlarged pectoral fins; (2) a second group laterally flattened with a wide protruding mouth, and (3) a third group strongly flattened with small pectorals fins. The following six trophic groups were organized based on prey categories: Zooplanktivores, Benthivores, Omnivores, Detritivores, Macrocarnivores and Insectivores. Significant results (PERMANOVA) between ecomorphological indices and habitat and between ecomorphological indices and trophic groups were found. These data indicate that similarity of ecomorphological forms, which minimize the influence of environment and partitioning of food, would help facilitate the co-existence of these fish when they are abundant in this tropical estuary.

Onze atributos ecomorfológicos e a dieta de dezessete espécies de peixes juvenis foram examinados para testar a hipótese de que os padrões morfológicos determinam a utilização dos recursos em habitats estuarinos. As espécies foram separadas de acordo com o modo de captura do alimento e uso do habitat (bentônicos ou pelágicos) em três grupos distintos: (1) um grupo de peixes depressiformes, com forte pedúnculo caudal e nadadeiras peitorais alargadas; (2) um segundo grupo, compressiforme, com ampla boca protrusível, e (3) um terceiro grupo, fortemente achatado e com pequenas nadadeiras peitorais. Seis grupos tróficos foram organizados com base nas categorias de presas: Zooplanctívoros, Bentívoros, Omnívoros, Detritívoros, Macrocarnívoros e Insetívoros. Foram encontrados resultados significativos (PERMANOVA) entre os índices ecomorfológicos e o habitat e entre os índices ecomorfológicos e os grupos tróficos. Estes dados indicam que a similaridade ecomorfológica, que reflete o ambiente e o tipo de alimento consumido, facilitaria a coexistência desses peixes quando estes são abundantes neste estuário tropical.

Keywords: Diets, Estuary, Habitats, Morphology, Resource partitioning.

\section{Introduction}

The organization of communities can be understood via the interaction of organisms and how species acquire and share resources with each other (Adite \& Winemiller, 1997). Fish are an excellent biological model to study this subject due to the great variety of morphological adaptations in their structures (e.g., shape of the mouth and fins), the type of the prey capture (e.g., foraging strategies) and feeding habits (Helfman et al., 2009). Most studies make reference to these morphological adaptations only through inferences from the analysis of the diet, regardless of the morphological variations (Dwyer et al., 2002; Hourston et al., 2004). A more promising approach that allows an understanding of how the enormous diversity of forms and functions of organisms influence their patterns of food resource utilization is the integration of ecomorphology studies (Winemiller, 1991; Piorski et al., 2005; Elliot et al., 2007; Teixeira \& Bennemann, 2007; Mazzoni et al., 2010; Sampaio \& Goulart, 2011).

Ecomorphology studies have focused on the relationship between changes in the morphology of individuals and ecological attributes related to the use of resources, based on the principle that the forms of organisms and their way of life are closely correlated (Teixeira \& Bennemann, 2007; Sampaio \& Goulart, 2011). There have been diverse attempts to conceptualize the interactions between morphology and ecology (Norton et al., 1995), and the choices of ecological and morphological characteristics are critical and should reflect those characters that research regards as most

\footnotetext{
${ }^{1}$ Universidade Estadual da Paraíba, Laboratório de Biologia Marinha, Avenida das Baraúnas, 351, Bairro Universitário, 58429-500 Campina Grande, PB, Brazil. (ALMP) andrepessanhauepb@gmail.com (corresponding author), (REMCCO) ronnie.enderson@gmail.com, (AFS) adna.biologia@hotmail.com, (NSS)natalicesantoss@gmail.com

${ }^{2}$ Universidade Federal Rural do Rio de Janeiro, Laboratório de Ecologia de Peixes, BR 465, Km 7, 23890-000 Seropédica, RJ, Brazil. (FGA) gerson@ufrrj.br
} 
important to the organism examined. In recent years, the primary focus has been the relationship between body shape and pattern in the use of prey, which is an effective tool in predicting patterns of use of environmental resources by teleosts and understanding the realized niche (Watson \& Balon, 1984; Wainwright \& Richard, 1995; Wainwright \& Bellwood, 2002; Nybakken \& Bertness, 2005; Costa \& Cataudella, 2007; Herler, 2007; Faye et al., 2012). The literature has placed more emphasis on fish assemblages in lakes (Adite \& Winemiller, 1997; Piorski et al., 2005), rivers (Willis et al., 2005), streams (Mazzoni et al., 2010) and reservoirs (Teixeira \& Bennemann, 2007). As a result, some investigators have proposed a series of relationships between different morphometric measurements, to infer about resource use: body/caudal fin and locomotor movements for the search and capture of prey (Webb, 1984); mouth gape, length of the intestine tract and the orientation of the mouth together with the presence of barbels were significantly correlated with the size, the type and the vertical position of the food, respectively (Piet, 1998); between the shape of the otoliths and depth (Volpedo \& Fuchs, 2010); larger eyes for sharper visual acuity; reduced mouth structures to match small prey sizes; and longer gill rakers to help retain captured prey in zooplanktivorous fishes (Schmitz \& Wainwright, 2011). However, for coastal areas of northeastern Brazil, few studies that address ecomorphological predictions have been performed in teleosts (Gomes et al., 2003; Medeiros \& Ramos, 2007; Piorski et al., 2007).

The marked relationship between ecomorphology and environmental variations observed in some freshwater environments might be different in tropical estuaries because these ecosystems contain fish assemblages with a species composition that is subject to different pressures and evolutionary histories (Blaber \& Blaber, 1980; Mazzoni et al., 2010). Currently, it is difficult to evaluate this hypothesis, since relatively few ecomorphological studies have been conducted in tropical estuaries. The present study evaluates the hypothesis that morphological patterns are correlated with different estuarine habitats, resource partitioning and therefore can be used as a tool in predicting the distribution of fishes in a tropical estuary in Brazil.

\section{Material and Methods}

Study site. The study was conducted in the rio Mamanguape estuary (6 $\left.63^{\prime} 02^{\prime \prime} \mathrm{S} 35^{\circ} 67^{\prime} 46^{\prime \prime} \mathrm{W}\right)$, which is the second largest estuary in the state of Paraíba (northeastern Brazil). The estuary is located in an environmental protection area ("EPA") Conselho Estadual de Recursos Hídricos do Estado da Paraíba (CERHLN, 2004), whose goal is to protect coastal ecosystems, as well as the marine manatee Trichechus manatus Linnaeus, 1758 (Mourão \& Nordi, 2003). The climate is tropical and humid, and the annual total rainfall varies from $2,000 \mathrm{~mm}$ to less than $30 \mathrm{~mm}$. Temperatures are high, and the mean annual temperature is between 24 and $26^{\circ} \mathrm{C}$ (Macedo et al., 2010). The beaches display a mesotidal, semi-diurnal tidal regime. The mouth of the river forms a $6-\mathrm{km}$-wide bay that is nearly closed off by a coastal reef line, which results in calm and quiet waters (Paludo \& Klonowski, 1999). In this area, well-preserved mangroves are present that are principally represented by Rhizophora mangle, Avicennia schaueriana, Avicennia germinans, Laguncularia racemosa, and Conocarpus erectus, which grow around the main channel and its intertidal creeks to encompass approximately 6,000 hectares, in addition to remnants of the Atlantic rainforest (Rocha et al., 2008).

Sampling. Samples were taken between October 2010 and September 2011, on monthly daytime excursions during spring tides. Sampling was carried out at six sites defined according to their locations relative to the river mouth: Camboa da Marcação (CMR) (6²7'15.84"S $\left.34^{\circ} 59^{\prime} 51.83^{\prime \prime} \mathrm{W}\right)$, is a shallow tidal creek located 13.07 $\mathrm{km}$ from the river mouth; Camboa dos Macacos (CMA) $\left(6^{\circ} 47^{\prime} 05.65^{\prime \prime S} 34^{\circ} 57^{\prime} 16.72^{\prime \prime} \mathrm{W}\right)$, a tidal creek located at an intermediate distance of $7.3 \mathrm{~km}$ from the mouth; Camboa

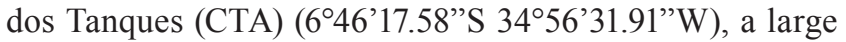
tidal creek located at $3.87 \mathrm{~km}$ from the mouth; Curva do

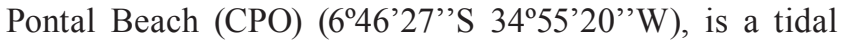
mudflat situated in the estuarine region $4.69 \mathrm{~km}$ from the mouth of the river; Pontal Beach (PON) (6 $46^{\circ} 22^{\prime \prime} \mathrm{S}$ $34^{\circ} 55^{\prime} 07^{\prime \prime} \mathrm{W}$ ), which is situated beyond the mouth of the rio Mamanguape and faces a stretch of reef $4.56 \mathrm{~km}$ from the mouth; and Campina Beach (CAM) (6 $48^{\circ} 43^{\prime \prime} \mathrm{S}$ $34^{\circ} 54^{\prime} 49^{\prime \prime} \mathrm{W}$ ), which has a larger influence from the ocean, located at a distance of $9 \mathrm{~km}$ from the river mouth (Fig. 1). Fishes were sampled using a beach seine net $(10 \mathrm{~m} \times 1.5$ $\mathrm{m}$, with an $8-\mathrm{mm}$ mesh) to capture juvenile fishes across a wide variety of habitats in estuary. The seine hauls were $30 \mathrm{~m}$ long, parallel to and close to the shore, and were used to a depth of approximately $1.5 \mathrm{~m}$. This procedure was replicated five times at each site.

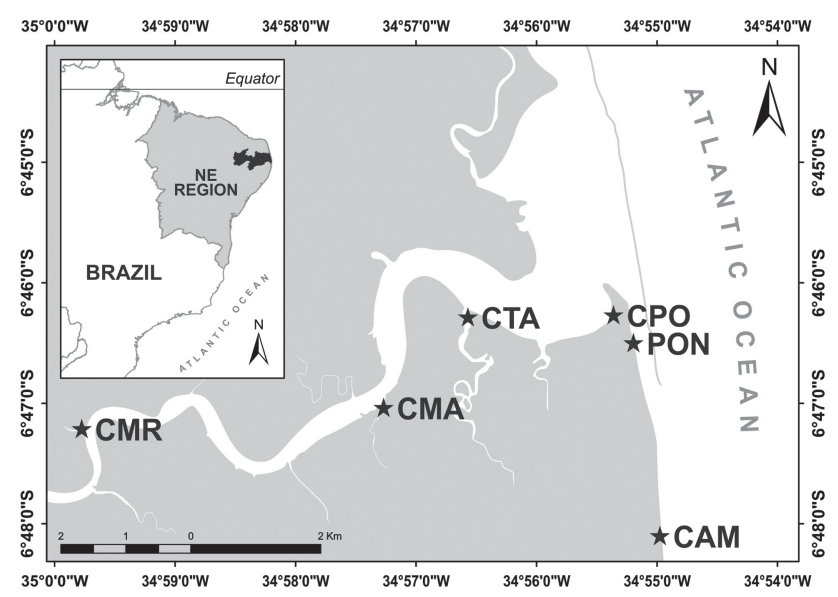

Fig. 1. Map indicating the location of the study area (rio Mamanguape estuary) on the coast of northeastern Brazil. $\mathrm{CMR}=$ Camboa da Marcação; $\mathrm{CMA}=$ Camboa dos Macacos; $\mathrm{CTA}=$ Camboa dos Tanques; $\mathrm{CPO}=$ Curva do Pontal Beach; $\mathrm{PON}=$ Pontal Beach; $\mathrm{CAM}=$ Campina Beach . 
Data and morphological variables. Species were chosen for analysis primarily according to abundance along the estuarine gradient. Sixteen morphological variables were measured based on Keast \& Webb (1966), Gatz (1979), Watson \& Balon (1984) and Beaumord \& Petrere Jr. (1994). A numeric vernier calliper $(0.1 \mathrm{~mm}$ precision) was used to measure: total length (TL), standard length (SL), body height (BH), mean body height (MHB), body width (BW), head length (HL), head height $(\mathrm{HH})$, relative eye height (ERH), pectoral fin length (PFL), pectoral fin width (PFW), caudal fin height $(\mathrm{CFH})$, caudal peduncle length (CPL), caudal peduncle height $(\mathrm{CPH})$, caudal peduncle width $(\mathrm{CPW})$, mouth width (WM) and mouth height (HM) (Fig. 2). Morphological measurements were transformed following the method of Schaefer (1992). Such transformations allow the removal of the body size effect, which standardises the measures, taking into account the effect of standard length on the analysed morphological attributes.
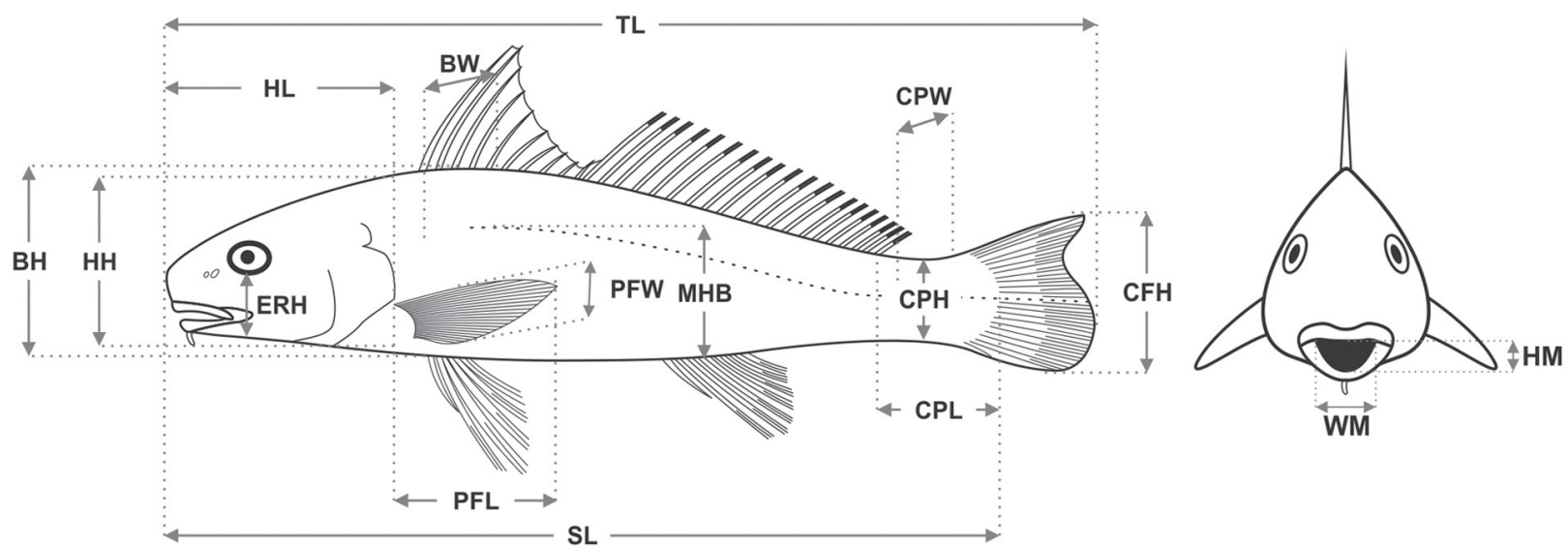

Fig. 2. A representative species, Menticirrhus littoralis, with sixteen morphological variables: total length (TL), standard length (SL), body height (BH), mean body height (MHB), body width (BW), head length (HL), head height (HH), relative eye height (ERH), pectoral fin length (PFL), pectoral fin width (PFW), caudal fin height (CFH), caudal peduncle length (CPL), caudal peduncle height (CPH), caudal peduncle width (CPW), mouth width (WM) and mouth height (HM).

From these measurements, a total of 11 ecomorphogical attributes were estimated:

Compression Index $(\mathrm{CI}=\mathrm{BH} / \mathrm{BW})$ (Watson \& Balon, 1984): Indicates the fish position in the water column; High values indicate a laterally compressed fish.

Relative Height $(\mathrm{RH}=\mathrm{BH} / \mathrm{SL})(\mathrm{Gatz}, 1979)$ : Directly related to the capacity for making vertical turns; Low values indicate an elongated fish.

Relative Peduncle Length $(\mathrm{RPL}=\mathrm{CPL} / \mathrm{SL})$ (Watson \& Balon, 1984): Long peduncles indicate fishes with good swimming ability.

Caudal Peduncle Compression Index $(\mathrm{CPCI}=\mathrm{CPH} /$ CPW) (Gatz, 1979): High values are typical of less active swimmers.

Index of ventral flattening (IVF $=\mathrm{MHB} / \mathrm{BH})$ (Watson \& Balon, 1984): Low values indicate fishes inhabiting waters with high hydrodynamism.

Aspect of Pectoral Fin Ratio $(\mathrm{APFR}=\mathrm{PFL} / \mathrm{PFW})$ (Keast \& Webb, 1966): Higher values indicate long and narrow fins.

Relative eyes position $(\mathrm{REP}=\mathrm{ERH} / \mathrm{BH})(\mathrm{Gatz}, 1979)$ : Indicates the vertical habitat preference. Benthic fishes have more dorsally located eyes and nektonic fishes have eyes laterally located.

Relative Head Length (RHL = HL/SL) (Watson \& Balon, 1984): Relatively larger heads indicate that the fish is able to handle larger prey.
Relative Mouth Width $(\mathrm{RMW}=\mathrm{WM} / \mathrm{SL})(\mathrm{Gatz}, 1979)$.

Relative mouth height $(\mathrm{RMH}=\mathrm{HM} / \mathrm{SL})($ Gatz, 1979): Mouth dimensions indicate, like head length, the relative size of eaten prey.

Mouth aspect ratio $($ MAR $=\mathrm{HM} / \mathrm{WM})($ Beaumord \& Petrere Jr., 1994): Mouth aspect ratio is related with the shape of the food; high values indicate narrow mouths, but large aperture.

Data analysis. Morphological variations were examined using principal component analysis (PCA). PCA was performed on the mean values of 11 ecomorphological attributes calculated. To evaluate the morphological affinities of each fish species a cluster analysis (Euclidian distance) was performed using the mean of the scores of the first and second principal components. We used single linkage clustering to produce dendrograms based on similarity. A cophenetic correlation analysis was employed to increase the reliability of conclusions drawn from the interpretation of the dendrogram. We adopted the cophenetic coefficient $(\mathrm{cc}=0.80)$ as the fidelity criterion for this analysis (Valentin, 2000). Statistical analysis was performed using PAST 2.16 software (Hammer et al., 2001).

The null hypothesis that the morphological patterns of the fish species are independent of habitats and trophic groups was tested using PERMANOVA. PERMANOVA tests (Permutational Multivariate Analysis of Variance) 
considering 9999 permutations were applied to know which of the groups were significantly distinct with regard to ecomorphogical indices underwent log transformation (log $\mathrm{x}+1$ ), using Euclidian distance matrix. The PERMANOVA was performed using PRIMER $6+$ PERMANOVA software.

Canonical Discriminant Analysis (CDA) was used to verify which ecomorphological indices were most important in the segregation of the species that constitute the trophic groups and exploited the habitats types. The canonical scores of individuals were projected in the reduced space of the canonical axes of the CDA contributed more to the discrimination of the body shape of analyzed groups (Oliveira et al., 2010).

Diet analysis. Stomach contents analysis was performed using a stereoscopic binocular microscope, and food items were identified to the lowest possible taxonomic level and grouped into the following food resources: plant material (plant and algal debris); Zooplankton (crustacean larvae, Calanoida and Cyclopoida copepods, invertebrates, and fish eggs); Insects (Diptera, Hymenoptera and Coleoptera adults; Chironimidae larvae); Polychaeta; Fish (scales and fish); Mollusca (Bivalvia, Gastropoda, and Scaphopoda); Decapoda (crabs and shrimp); Benthic or Epibenthic crustaceans (Isopoda, Tanaidacea, Ostracoda, Caprella amphipods, Mysidacea, Gammaridea amphipods, Harpacticoida copepods, and Cirripedia); Infauna (Foraminifera, Sipuncula, Nematoda, and Trematoda); and Phytobenthos (diatoms) (Inoue et al., 2004). The volumes of each items was obtained according Bemvenuti (1990) and analyzed by displacement methods. The separate items were evenly compressed between two glass plates and volume recorded on a Petri dish with a 100 grid points. Prey items and fragments falling upon each of the 100 grid points were counted and volume was recorded. The total volumes of each item were obtained by summing individual volumes across all samples. The volumetric proportion of each item was then calculated on the basis of the total volume of food eaten per consumer.

\section{Results}

Ecomorphology. A total of 550 individuals, belonging to 17 species, 13 families and 6 orders, were measured (Table 1), and nearly all individuals were juveniles, ranging from 52-236 $\mathrm{mm}$ TL. The ecomorphological index values calculated for each species and the number of individuals used is shown in Table 2.

The results of PERMANOVA tests revealed that there are significant differences between the matrices of ecomorphological indices vs. habitats (Pseudo $\mathrm{F}_{2.505}=9.77$, $\mathrm{p}=0.0001)$ and ecomorphological indices $v s$ trophic groups (Pseudo $\mathrm{F}_{5.505}=18.90, \mathrm{p}=0.0001$ ).

The first two principal components ( $\mathrm{PC1}$ and $\mathrm{PC} 2)$ explained $92.33 \%$ of the variation in morphological attributes: $\mathrm{PC} 1$ explained $85.78 \%$ and $\mathrm{PC} 2,6.56 \%$ of the variation (Fig. 3). High scores on PC1 were associated with the caudal peduncle compression index (CPCI) and the compression Index (CI), whereas low scores were associated with the relative eye position (REP) and index of ventral flattening (IVF) (Fig. 3). High scores on PC2 were associated with the compression index $(\mathrm{CI})$ and mouth aspect ratio (MAR), whereas low scores were associated with the caudal peduncle compression Index (CPCI) and relative eye position (REP) (Fig. 3).

Table 1. Fish species recorded in the rio Mamanguape estuary (PB), species identifications and range of total length (mm). Max $=$ maximum; Min = minimum.

\begin{tabular}{|c|c|c|c|c|}
\hline \multirow[b]{2}{*}{ Family } & \multirow[b]{2}{*}{ Species } & \multirow[b]{2}{*}{ Label } & \multicolumn{2}{|c|}{ Total length (mm } \\
\hline & & & Min & Max \\
\hline Clupeidae & Rhinosardinia bahiensis (Steindachner, 1879) & RHBA & 81 & 106 \\
\hline \multirow[t]{2}{*}{ Engraulidae } & Anchovia clupeoides (Swainson, 1839) & ANCL & 103 & 134 \\
\hline & Lycengraulis grossidens (Spix \& Agassiz, 1829) & LYGR & 77 & 214 \\
\hline Hemiramphidae & Hyporhamphus unifasciatus (Ranzani, 1841) & HYUN & 161 & 202 \\
\hline Atherinopsidae & Atherinella brasiliensis (Quoy \& Gaimard, 1825) & ATBR & 113 & 180 \\
\hline Centropomidae & Centropomus undecimalis (Bloch, 1792) & CEUN & 63 & 220 \\
\hline \multirow[t]{3}{*}{ Carangidae } & Caranx latus Agassiz, 1831 & CALA & 60 & 151 \\
\hline & Oligoplites saurus (Bloch \& Schneider, 1801) & OLSA & 52 & 103 \\
\hline & Trachinotus goodei Jordan \& Evermann, 1896 & TRGO & 71 & 153 \\
\hline Lutjanidae & Lutjanus synagris (Linnaeus, 1758) & LUSY & 56 & 157 \\
\hline Gerreidae & Eugerres brasilianus (Cuvier, 1830) & EUBR & 52 & 99 \\
\hline Sciaenidae & Menticirrhus littoralis (Holbrook, 1847) & MELI & 52 & 103 \\
\hline \multirow[t]{2}{*}{ Gobiidae } & Bathygobius soporator (Valenciennes, 1837) & BASO & 79 & 124 \\
\hline & Gobionellus oceanicus (Pallas, 1770) & GOOC & 160 & 220 \\
\hline Paralichthyidae & Citharichthys spilopterus Günther, 1862 & CISP & 80 & 143 \\
\hline Achiridae & Achirus lineatus (Linnaeus, 1758) & ACLI & 53 & 175 \\
\hline Tetraodontidae & Sphoeroides testudineus (Linnaeus, 1758) & SPTE & 140 & 236 \\
\hline
\end{tabular}


Table 2. Means (M) and standard errors (SE) for the 11 ecomorphological attributes calculated for 17 fish species analysed. Codes for species as in Table I. CI = compression index; RH = relative height; RPL = relative peduncle length; $\mathrm{CPCI}=$ caudal peduncle compression index; IVF = index of ventral flattening; APFR = aspect of pectoral fin ratio; REP = relative eye position; $\mathrm{RHL}=$ relative head length; $\mathrm{RMW}=$ relative mouth width; $\mathrm{RMH}=$ relative mouth height; $\mathrm{MAR}=$ mouth aspect ratio.

\begin{tabular}{|c|c|c|c|c|c|c|c|c|c|c|c|c|c|}
\hline Spp & $\mathrm{n}$ & & CI & $\mathrm{RH}$ & RPL & CPCI & IVF & APFR & REP & RHL & RMW & $\mathrm{RMH}$ & MAR \\
\hline \multirow{2}{*}{ RHBA } & \multirow{2}{*}{40} & $\mathrm{M}$ & 2.68 & 0.23 & 0.13 & 3.07 & 0.72 & 2.90 & 0.33 & 0.22 & 0.03 & 0.07 & 2.31 \\
\hline & & $\pm \mathrm{SE}$ & 0.04 & 0.01 & 0.01 & 0.10 & 0.01 & 0.14 & 0.01 & 0.01 & $<0.01$ & $<0.01$ & 0.14 \\
\hline \multirow{2}{*}{ ANCL } & \multirow{2}{*}{40} & $\mathrm{M}$ & 3.18 & 0.25 & 0.12 & 3.31 & 0.77 & 2.65 & 0.19 & 0.28 & 0.06 & 0.15 & 2.82 \\
\hline & & $\pm \mathrm{SE}$ & 0.06 & $<0.01$ & $<0.01$ & 0.12 & 0.02 & 0.13 & 0.01 & $<0.01$ & $<0.01$ & 0.01 & 0.22 \\
\hline \multirow{2}{*}{ LYGR } & \multirow{2}{*}{40} & M & 2.35 & 0.21 & 0.15 & 2.76 & 0.74 & 2.50 & 0.25 & 0.25 & 0.06 & 0.14 & 2.36 \\
\hline & & $\pm \mathrm{SE}$ & 0.06 & 0.01 & 0.01 & 0.12 & 0.01 & 0.16 & 0.01 & 0.01 & $<0.01$ & 0.01 & 0.17 \\
\hline \multirow{2}{*}{ HYUN } & \multirow{2}{*}{40} & $\mathrm{M}$ & 1.42 & 0.08 & 0.05 & 2.16 & 0.82 & 2.76 & 0.28 & 0.39 & 0.04 & 0.04 & 1.05 \\
\hline & & $\pm \mathrm{SE}$ & 0.03 & $<0.01$ & $<0.01$ & 0.06 & 0.02 & 0.11 & 0.01 & $<0.01$ & $<0.01$ & $<0.01$ & 0.03 \\
\hline \multirow{2}{*}{ ATBR } & \multirow{2}{*}{40} & $\mathrm{M}$ & 1.44 & 0.17 & 0.14 & 2.26 & 0.77 & 2.61 & 0.23 & 0.23 & 0.06 & 0.06 & 0.99 \\
\hline & & $\pm \mathrm{SE}$ & 0.03 & $<0.01$ & 0.01 & 0.09 & 0.02 & 0.11 & 0.01 & $<0.01$ & $<0.01$ & $<0.01$ & 0.06 \\
\hline \multirow{2}{*}{ CEUN } & \multirow{2}{*}{15} & $\mathrm{M}$ & 2.18 & 0.24 & 0.22 & 3.53 & 0.72 & 4.15 & 0.31 & 0.40 & 0.10 & 0.17 & 1.65 \\
\hline & & $\pm \mathrm{SE}$ & 0.07 & 0.01 & 0.01 & 0.27 & 0.03 & 0.36 & 0.02 & 0.01 & 0.01 & 0.01 & 0.08 \\
\hline \multirow{2}{*}{ CALA } & \multirow{2}{*}{40} & $\mathrm{M}$ & 3.07 & 0.41 & 0.08 & 1.04 & 0.73 & 2.74 & 0.35 & 0.35 & 0.11 & 0.13 & 1.22 \\
\hline & & $\pm \mathrm{SE}$ & 0.07 & 0.01 & $<0.01$ & 0.03 & 0.02 & 0.13 & 0.01 & 0.01 & $<0.01$ & 0.01 & 0.09 \\
\hline \multirow{2}{*}{ OLSA } & \multirow{2}{*}{15} & $\mathrm{M}$ & 3.44 & 0.28 & 0.08 & 1.98 & 0.72 & 2.51 & 0.38 & 0.27 & 0.09 & 0.11 & 1.36 \\
\hline & & $\pm \mathrm{SE}$ & 0.35 & 0.01 & 0.01 & 0.16 & 0.04 & 0.28 & 0.07 & 0.01 & 0.01 & 0.02 & 0.14 \\
\hline \multirow{2}{*}{ TRGO } & \multirow{2}{*}{15} & $\mathrm{M}$ & 2.92 & 0.44 & 0.13 & 2.54 & 0.64 & 2.26 & 0.29 & 0.32 & 0.15 & 0.15 & 0.92 \\
\hline & & $\pm \mathrm{SE}$ & 0.22 & 0.04 & 0.02 & 0.21 & 0.02 & 0.13 & 0.03 & 0.02 & 0.02 & 0.03 & 0.07 \\
\hline \multirow{2}{*}{ LUSY } & \multirow{2}{*}{15} & M & 2.55 & 0.39 & 0.22 & 3.25 & 0.81 & 3.29 & 0.49 & 0.38 & 0.20 & 0.21 & 1.01 \\
\hline & & $\pm \mathrm{SE}$ & 0.26 & 0.03 & 0.03 & 0.36 & 0.13 & 0.53 & 0.06 & 0.02 & 0.04 & 0.05 & 0.09 \\
\hline \multirow{2}{*}{ EUBR } & \multirow{2}{*}{40} & $\mathrm{M}$ & 3.52 & 0.41 & 0.14 & 3.85 & 0.63 & 4.05 & 0.28 & 0.34 & 0.07 & 0.08 & 1.28 \\
\hline & & $\pm \mathrm{SE}$ & 0.10 & 0.01 & 0.01 & 0.13 & 0.01 & 0.16 & 0.01 & 0.01 & $<0.01$ & 0.01 & 0.08 \\
\hline \multirow{2}{*}{ MELI } & \multirow{2}{*}{15} & M & 1.46 & 0.21 & 0.28 & 2.61 & 0.69 & 2.62 & 0.36 & 0.30 & 0.09 & 0.08 & 0.74 \\
\hline & & $\pm \mathrm{SE}$ & 0.09 & 0.01 & 0.02 & 0.15 & 0.02 & 0.11 & 0.02 & 0.02 & 0.01 & 0.02 & 0.10 \\
\hline \multirow{2}{*}{ BASO } & 40 & $\mathrm{M}$ & 1.16 & 0.21 & 0.22 & 3.01 & 0.76 & 2.32 & 0.46 & 0.30 & 0.13 & 0.10 & 0.75 \\
\hline & 40 & $\pm \mathrm{SE}$ & 0.04 & 0.01 & 0.01 & 0.17 & 0.03 & 0.30 & 0.02 & 0.01 & $<0.01$ & 0.01 & 0.03 \\
\hline GคคC & 15 & $\mathrm{M}$ & 1.34 & 0.14 & 0.10 & 3.68 & 0.72 & 2.08 & 0.51 & 0.18 & 0.07 & 0.06 & 0.91 \\
\hline Gove & 15 & $\pm \mathrm{SE}$ & 0.05 & 0.01 & 0.01 & 0.31 & 0.05 & 0.16 & 0.04 & 0.01 & $<0.01$ & 0.01 & 0.06 \\
\hline CISP & 15 & $\mathrm{M}$ & 6.62 & 0.41 & 0.04 & 9.61 & 0.57 & 3.73 & 0.21 & 0.30 & 0.05 & 0.12 & 3.06 \\
\hline CIDI & 10 & $\pm \mathrm{SE}$ & 0.51 & 0.02 & $<0.01$ & 1.23 & 0.07 & 0.22 & 0.03 & 0.03 & 0.01 & 0.03 & 0.58 \\
\hline 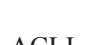 & A & M & 7.78 & 0.77 & 0.04 & 9.02 & 0.49 & 3.28 & 0.21 & 0.29 & 0.05 & 0.09 & 1.61 \\
\hline ACLI & 40 & $\pm \mathrm{SE}$ & 0.30 & 0.04 & $<0.01$ & 0.45 & 0.02 & 0.16 & 0.02 & 0.01 & $<0.01$ & 0.01 & 0.14 \\
\hline & & $\mathrm{M}$ & 0.95 & 0.26 & 0.23 & 1.58 & 0.57 & 1.33 & 0.59 & 0.36 & 0.10 & 0.07 & 0.65 \\
\hline SPTE & 40 & $\pm \mathrm{SE}$ & 0.01 & 0.01 & 0.01 & 0.10 & 0.02 & 0.05 & 0.01 & 0.01 & 0.01 & 0.01 & 0.03 \\
\hline
\end{tabular}

Species with more positive scores on the first axis show more lateral peduncles and reduced pectoral fins, represented by Achirus lineatus and Citharichthys spilopterus, which remain close the bottom and are characterised as having the most extreme morphologies of bottom fish. Species that had a more flattened body and wide mouth were plotted at the other extreme in the PCA diagram, represented principally by Bathygobius soporator, Gobionellus oceanicus, Lycengraulis grossidens and Anchovia clupeoides (Fig. 4). The second axis (PC2) formed a group on positive scores that included species with a laterally compressed body and narrow mouth (but with a large opening), such as Caranx latus and Oligoplites palometa; species characterized by a highly developed caudal peduncles; and eyes placed dorsally such as Sphoeroides testudineus, B. soporator and G. oceanicus. A combination of these variables along the PC1 and PC2 axis allowed identification of important features for species distinction, such as hydrodynamic morphology and relative width and height of mouth.

The cluster formed based on scores (cophenetic coefficient $\mathrm{cc}=0.975$ ) comprised three groups: the first (Group 1) with six species, which had a body form from depressed to streamlined shapes, with strong caudal peduncles and enlarged pectoral fins; the second (Group 2 ), with nine species with intermediate forms, which had a body form from laterally flattened to a wide protusible mouth, and the third (Group 3), with two species that were strongly flattened and had small pectorals fins (Fig. 5). 


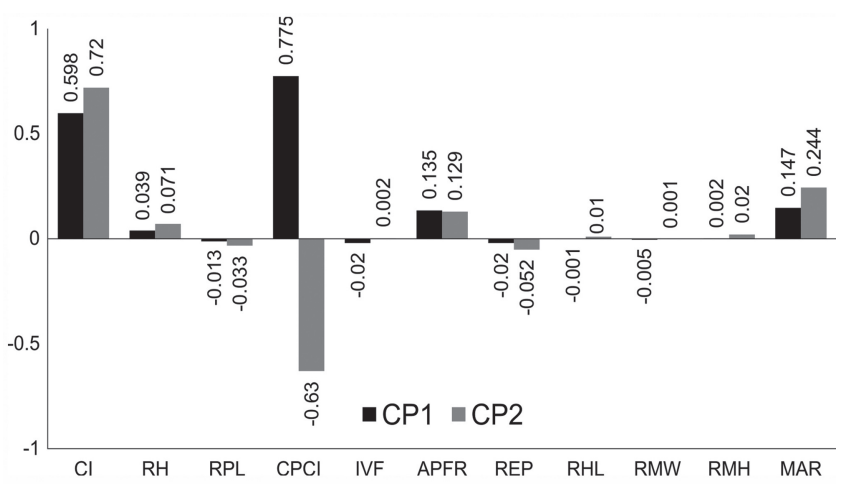

Fig. 3. Factor loads from principal component analysis on ecomorphological attributes of selected fish species. $\mathrm{CI}=$ compression index; $\mathrm{RH}=$ relative height; $\mathrm{RPL}=$ relative peduncle length; $\mathrm{CPCI}=$ caudal peduncle compression index; IVF = index of ventral flattening; $A P F R=$ aspect of pectoral fin ratio; REP $=$ relative eye position; $\mathrm{RHL}=$ relative head length; RMW = relative mouth width; RMH $=$ relative mouth height; $\mathrm{MAR}=$ mouth aspect ratio.

The models predicted by CDA showed the ecomorphological indices that most contributed to the discrimination among the habitat and trophic groups.
The first canonical axis of the CDA, applied to the habitat (73.7\% of explained variability), demonstrated that there was a segregation by habitat, with individuals with larges caudal peduncles and body flattened, while the second (26.3\% of explained variability) were associated with larger eyes position and pelvic fins, and large mouth opening (Fig. 6).

The results of the CDA models of the trophic groups showed the first canonical axis $(62.6 \%$ of explained variability), demonstrated that there was a segregation of the omnivores, detritivores and zooplanktivores with more positive scores, and insectivores and benthivores with negative scores (Fig. 7). The first three trophic groups presented body height, longer and wider peduncles and eyes, and the other extreme of axis 1 are insectivores and benthivores that revealed longer heads and higher values for compression indices. On the second axis (16.3\% of explained variability) there was a segregation of the detritivores, zooplanktivores and benthivores (positive scores) of omnivores and insectivores (negative scores). In this case, larger pelvic fins and wider mouth were attributed to detritivores and benthivores, while higher mouth aspect ratio characterize the omnivores and insectivores (Fig. 7).

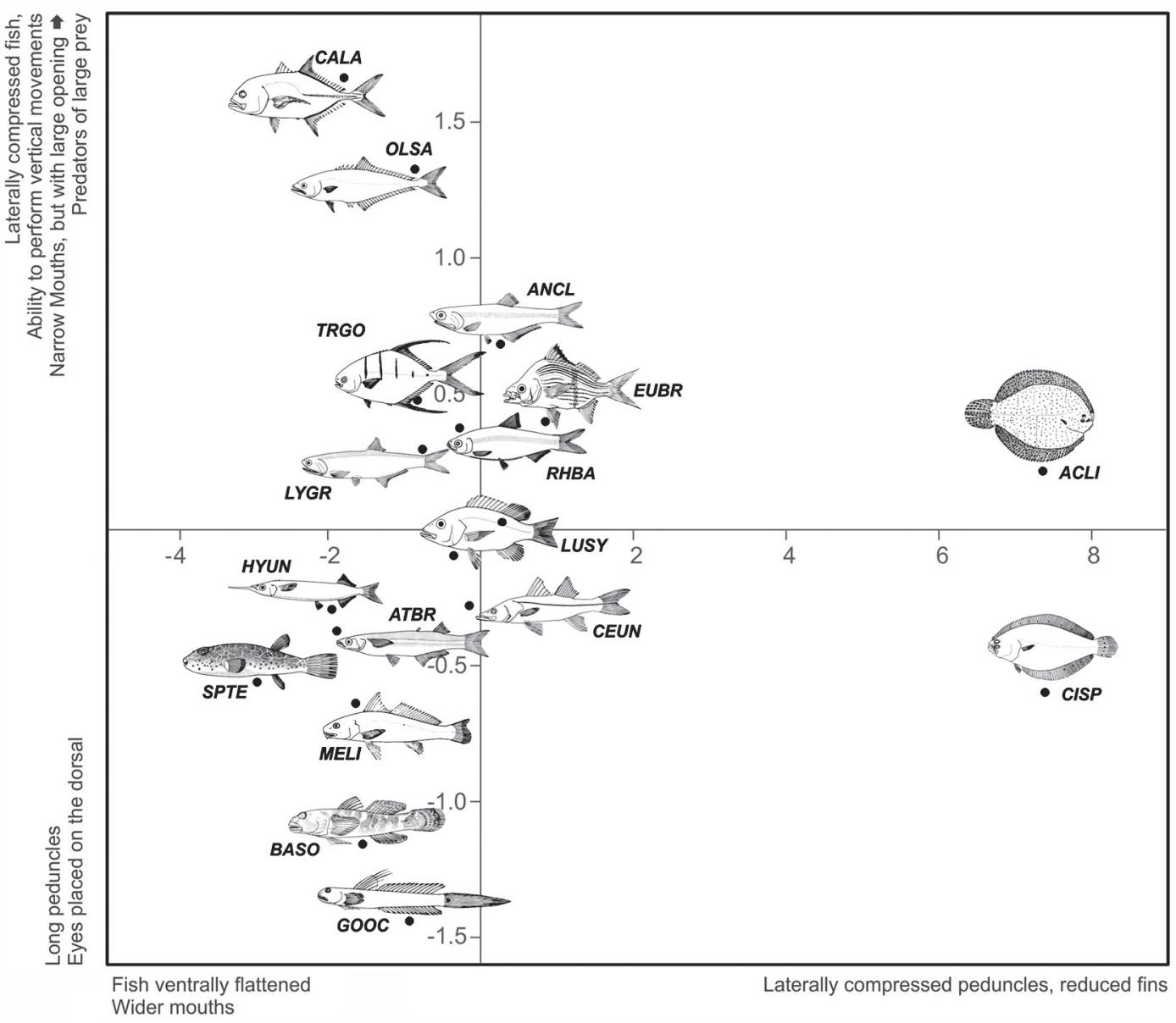

Fig. 4. Ordination diagram for the rio Mamanguape estuary, from the first two principal components for the ecomorphological attributes of seventeen studied species. The codes for species are as in Table 1. 


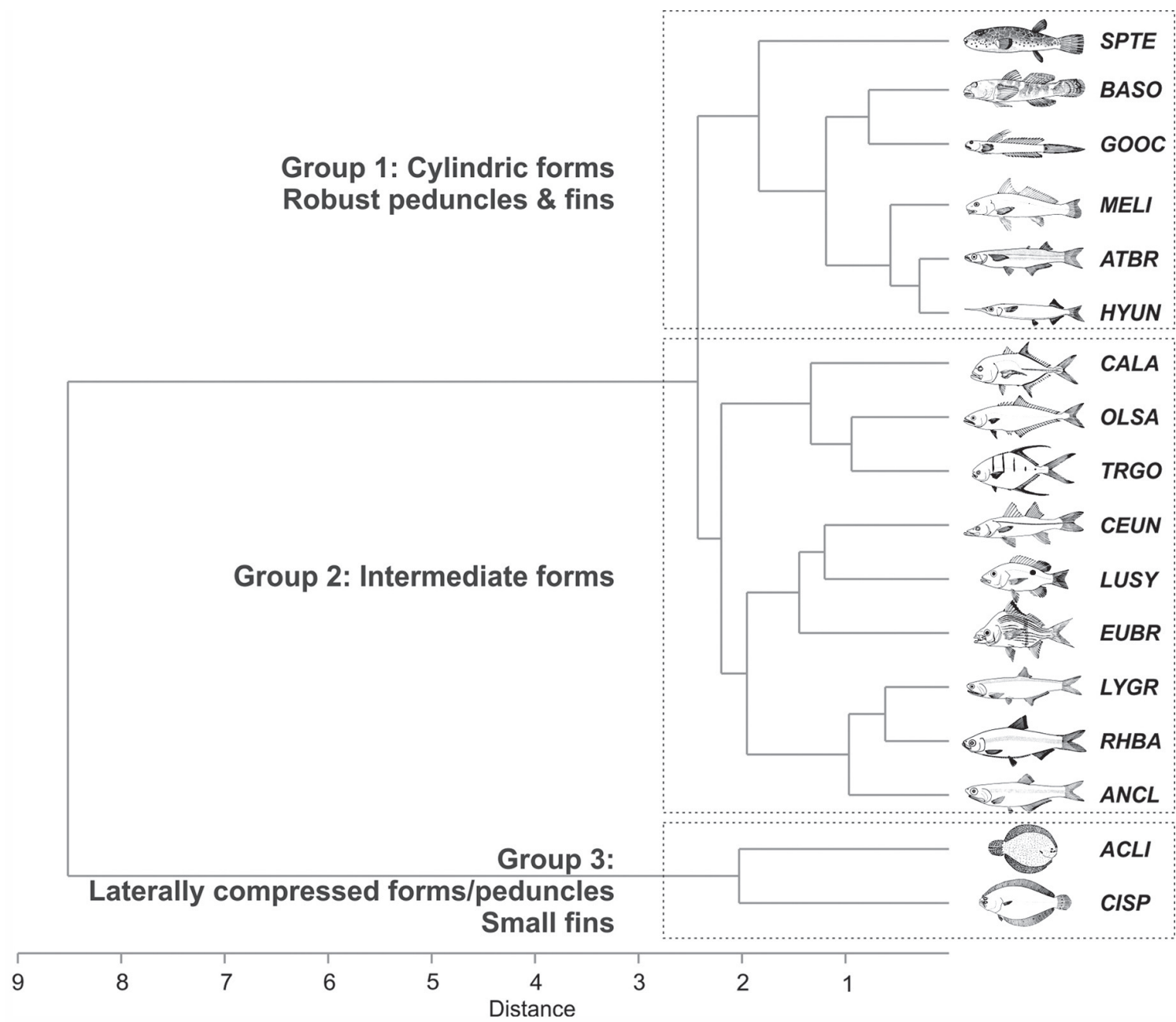

Fig. 5. Dendrogram from cluster analysis for ecomorphological attributes of seventeen fish species in the rio Mamanguape estuary. The code for species is as in Table 1.

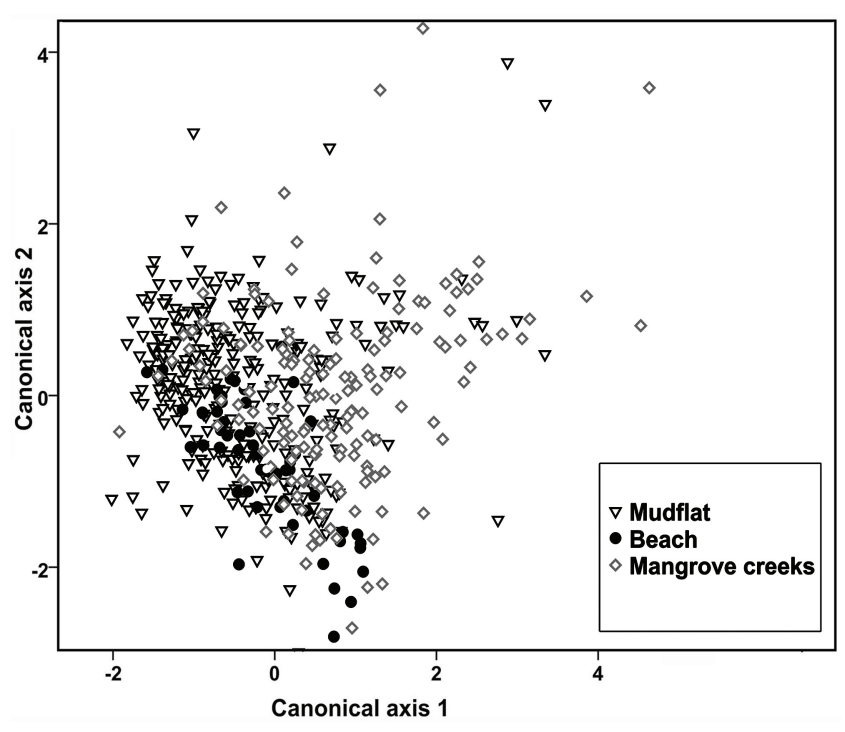

Fig. 6. Diagram of Canonical Discriminant Analysis for the ecomorphological indices of the fishes grouping in habitat types in the rio Mamanguape estuary (Mudflat, Beach and Mangrove creeks).

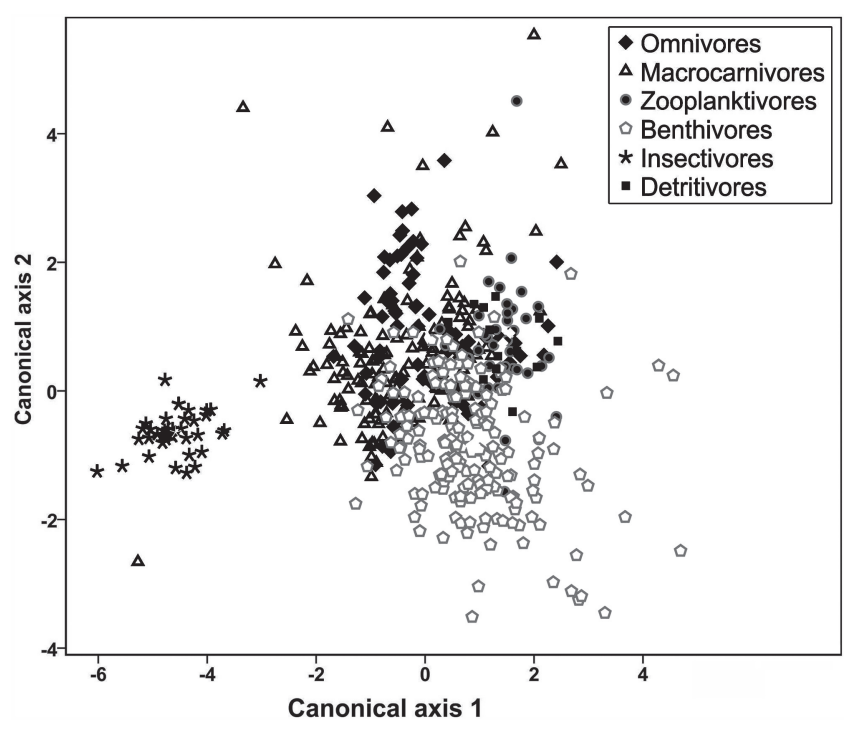

Fig. 7. Diagram of Canonical Discriminant Analysis for the ecomorphological indices of the fishes grouping in trophic guilds in the rio Mamanguape estuary. 
Diet Composition. The fish species can be classified into six trophic groups based on the proportions of the different functional prey categories (Table 3). The detritivore group was comprised of Gobionellus oceanicus, which fed mainly on detritus associated with diatoms. Benthivores included six species, whose diet was dominated by Molluscs,
Polychaeta, Decapoda and Benthic Crustacea, whereas zooplanktivores were represented by Rhinosardinia bahiensis, which fed mainly on copepods and decapoda larvae. Macrocarnivores had a diet composed of over $50 \%$ of fishes or Decapoda. Bathygobius soporator and Anchovia clupeoides were classified as omnivorous species.

Table 3. Volumetric proportions of the ten food resources identified in seventeen species in the tropical estuary. (Plts = plant material; $\mathrm{Zkpl}=$ Zooplankton Polych $=$ Polychaeta $;$ Moll = Mollusca $;$ Decap = Decapoda Bentcrus = benthic or epibenthic Crustaceans; Phytoben $=$ Phytobenthos).

\begin{tabular}{lllllllllllll}
\hline Species & $\mathrm{n}$ & Plts & Zkpl & Insect & Polych & Fish & Moll & Decap & Bentcru & Infauna & Phytoben & Trophic group \\
\hline A. clupeoides & 380 & 35.85 & 34.81 & 0.05 & 3.22 & 5.35 & 5.09 & 0.25 & 3.79 & 5.14 & 0.37 & Omnivores \\
L. grossidens & 178 & 0.35 & 0.35 & 0.00 & 0.00 & 7.80 & 0.14 & 86.62 & 1.47 & 3.24 & 0.01 & Macrocarnivores \\
R. bahiensis & 274 & 0.53 & 85.65 & 0.00 & 0.07 & 0.38 & 7.30 & 0.33 & 3.75 & 1.57 & 0.37 & Zooplanktivores \\
A. brasiliensis & 449 & 23.60 & 11.71 & 5.27 & 0.00 & 1.83 & 55.42 & 0.72 & 0.93 & 0.35 & 0,12 & Benthivores \\
H. unifasciatus & 197 & 4.53 & 22.50 & 57.99 & 0.12 & 0.27 & 7.96 & 0.02 & 0.73 & 0.41 & 0.22 & Insectivores \\
C. undecimalis & 19 & 0.00 & 0.14 & 0.00 & 0.00 & 96.91 & 0.00 & 1.79 & 0.00 & 0.00 & 0.00 & Macrocarnivores \\
O. saurus & 16 & 0.16 & 9.83 & 3.77 & 4.59 & 77.86 & 0.16 & 2.62 & 0.00 & 1.21 & 0.00 & Macrocarnivores \\
C. latus & 21 & 0.00 & 22.97 & 0.00 & 0.82 & 54.74 & 0.05 & 10.81 & 4.34 & 5.58 & 0.01 & Macrocarnivores \\
T. goodei & 34 & 6.87 & 0.07 & 24.63 & 12.80 & 0.01 & 2.33 & 10.97 & 42.28 & 0.01 & 0.00 & Benthivores \\
L synagris & 19 & 0.00 & 1.49 & 0.00 & 0.08 & 15.48 & 0.00 & 82.45 & 0.36 & 0.00 & 0.12 & Macrocarnivores \\
E. brasilianus & 219 & 1.46 & 73.98 & 0.02 & 20.58 & 0.13 & 0.59 & 0.22 & 1.14 & 1.66 & 0.00 & Zooplanktivores \\
M. littoralis & 40 & 1.14 & 0,10 & 0.00 & 29.51 & 0.20 & 2.63 & 54.91 & 11.29 & 0.03 & 0.00 & Benthivores \\
B. soporator & 16 & 81.74 & 0.00 & 0.00 & 0.00 & 0.00 & 0.02 & 18.46 & 0.00 & 0.00 & 0.00 & Omnivores \\
G. oceanicus & 16 & 0.04 & 4.01 & 0.00 & 0.04 & 0.00 & 1.00 & 0.00 & 0.04 & 0.58 & 95.26 & Detritivores \\
A. lineatus & 51 & 4.74 & 1.83 & 0.28 & 54.62 & 1.90 & 0.00 & 35.12 & 0.14 & 0.21 & 0.00 & Benthivores \\
C. spilopterus & 30 & 0.00 & 13.14 & 0.78 & 0.19 & 80.73 & 0.06 & 4.88 & 0.00 & 0.19 & 0.01 & Macrocarnivores \\
S. testudineus & 178 & 0.33 & 1.74 & 4.48 & 6.76 & 1.91 & 21.81 & 27.03 & 34.95 & 0.78 & 0.15 & Benthivores \\
\hline
\end{tabular}

\section{Discussion}

In this study, the hypothesis that differences in morphological patterns imply different forms of resource exploitation was accepted. Thus, the results of cluster analysis showed a separation of species according to the explored environment, one group associated with mouth gape and another with the form of locomotion (benthic or pelagic). Morphology is a good predictor of resource use by fishes, to indicate which strategies are used as adaptations to environmental conditions (Douglas \& Matthews, 1992; Peres-Neto, 2004). It is known that several habitat characteristics and environmental factors can influence community structure and play a role in species distribution and community organization, exceeding that played by biotic factors. Coexistence in many fish assemblages is due to morphological and spatial segregation (Boyle \& Horn, 2006; Costa \& Cataudella, 2007; Sampaio et al., 2013).

On the first axis, two extreme groups were observed in morphospace, one formed by species with a small mouth gape, extremely compressed body and benthic habits and another with species showing larger mouth gape and compressed or flattened bodies, representatives of pelagic and epibenthic habits. For flatfish, distribution in the bottom is based on camouflage ability as a tactic to capture prey or escape predators (Guedes \& Araújo, 2008), whereas for epibenthic species, pectoral fins and a well-developed caudal peduncle are important in propulsion and to prevent the body from rolling over (Adriaens et al., 1993). Developed caudal peduncles and pectoral fins are fundamental to the stabilization of the body of benthic species in the bottom (Oliveira et al., 2010).

For the second axis, the species located in the upper and median morphospace were grouped by having a more compressed body, which is an important morphological attribute for better manoeuvring. Fishes with a compressed body are more agile in the water column and perform better in habitats that are structurally more complex or have a lower current velocity (Oliveira et al., 2010; Faye et al., 2012). In structurally complex environments such as reefs, the swimming performance and the importance of body orientation has been highlighted with important implications for habitat use and other aspects of their ecology (Wainwright et al., 2002). In this study, Centropomus undecimalis and Lutjanus synagris were captured mainly in the mangrove creeks, where the prop-root environment of mangroves is high, and certain manoeuvres are important for protection from predators and to obtain food (Osório et al., 2011). Alternatively, these and others manoeuvres in open water are used to position the body to suck small prey items from the water column. 
The results of cluster analysis showed the same pattern of PCA. Group 1 was represented by species that exploit the bottom at locations with different morphodynamics for ingestion of food items: Menticirrhus littoralis explored sandy areas such as exposed beaches, preying on Polychaeta, whereas B. soporator, G. oceanicus and S. testudineus were distributed in areas of lower hydrodynamics already inside the estuary, consuming prey on the bottom, such as Diatoms and Mollusca (Palmeira \& Monteiro-Neto, 2010; Chi-Spínola \& Veja-Cendejas, 2013). The subterminal mouth is indicative of similarity in food acquisition of organisms of the bottom. The size, shape and position of the mouth are also considered to be highly adaptive and relate to the way of foraging (Chao \& Musick, 1977; Kotrschal, 1989). Ecomorphological studies show the importance of considering the type of fish mouth because the mechanical action is differentiated to capture different types of available food resources (Motta et al., 1995).

Small fish with a flattened head, long pectoral fins and modified pelvis to adhere to the bottom, such as B. soporator and G. oceanicus, which are called bottom clingers (Moyle $\&$ Cech, 2004), are found in intertidal areas. Representative of silversides, Atherinella brasiliensis, have long pectoral fins, which allow better maneuverability and movement, since these fish forage items in the mid-water column as the bottom (Gibran, 2010). Such phenotypic characteristics can be allocated to species in the dendrogram and morphospace.

Group 2 was comprised by species that have very pronounced protusions, a wide mouth and large eyes, and was represented by Perciformes and Clupeiformes. Suctionfeeding modes involve a rapid expansion of the buccal cavity, followed or not by jaw protusion, a feature that is observed in benthic invertebrate feeders (Eugerres brasilianus), piscivores (C. undecimalis) or macrocarnivores (L. synagris) (Wainwhright et al., 2006; Freitas et al., 2011; VasconcelosFilho et al., 2011). Also in Group 2 are grouped species of Carangidae: C latus, Oligoplites saurus and Trachinotus goodei, which have characteristics such as a high degree of lateral flattening and slender caudal peduncles, indicative of good swimmers that inhabit the mid-water column. These species have a pronounced body height, which leads to a compressed body, facilitating the capture of fast prey such as fish and decapods (Palmeira \& Monteiro-Neto, 2010).

For Clupeiformes, a small head and large eyes indicate the importance of such features in capturing small prey in the mid-water column. Large eyes indicate a high visual acuity for these species, developed to capture prey such as copepods and decapod larvae (Maes \& Ollevier, 2002). Zooplanktivores are filter-feeders that engulf a large amount of water and then collect the small suspended particles in their gill raker sieve (Faye et al., 2012). The compressed body shape in $R$. bahiensis is the result of a sharp ventral kell, which functions to camouflage these silvery fish by eliminating ventral shadows, thus making them less visible to predators approaching from below (Moyle \& Cech, 2004).
The Pleuronectiformes were placed together in Group 3, due to their body shape and size of their pectoral fins. For $C$. spilopterus and $A$. lineatus, pectoral fins are not widely used in swimming and stabilize the body; long dorsal and anal fins together with a flexible tail respond to the propulsive undulation of the body in this species. Part of the swimming power of plaice, the induced power, is used to generate lift and to support the weight of the fish in water (Webb, 2002). Moreover, a function assigned to the pectoral fin in this group is related to tigmotactism and decreased body weight support (Marsh, 1977).

Based on the results here, it is possible to verify that there was a similarity of ecomorphological forms that reflect the environment and the type of food used by the studied species. The main trophic groups were macrocarnivores and benthivores, whose resource partitioning occurs due to a diversification in morphological attributes, thereby reducing overlap within this tropical estuary.

\section{Acknowledgements}

We thank biologists Nathalia I. Medeiros, Gabriela G. A. Abrantes, Bianca B. F. Soares and Renato P. Dantas for helping in field work. This work was partially supported by the Sistema Nacional de Pesquisa em Biodiversidade (SISBIOTA/BRAZIL) and CNPq - Conselho Nacional de Desenvolvimento Científico e Tecnológico (Proc. 563202/2010-6 and Proc. 477663), SISBIO gave permission to carry out the research in the protected area (Proc. 24557).

\section{References}

Adite, A. \& K. O. Winemiller. 1997. Trophic ecology and ecomorphology of fish assemblages in coastal lakes of Benin, West Africa. Ecoscience, 4: 6-23.

Adriaens, D., D. Decleyre \& W. Verraes. 1993. Morphology of the pectoral girdle in Pomatoschistus lozanoi De Buen, 1923 (Gobiidae), in relation to pectoral fin adduction. Belgian Journal of Zoology, 123: 135-157.

Beaumord, A. C. \& M. Petrere Jr. 1994. Fish communities of Manso River, Chapada dos Guimarães, MT, Brazil. Acta Biologica Venezuelica, 152: 21-35.

Bemvenuti, M. A. 1990. Hábitos alimentares de peixes-rei (Atherinidae) na região estuarina da Lagoa dos Patos, RS, Brasil. Atlântica, 12: 79-102.

Blaber, S. J. M. \& T. G. Blaber. 1980. Factors affecting the distribution of juvenile estuarine and inshore fish. Journal of Fish Biology, 17: 143-162.

Boyle, K. S. \& M. H. Horn. 2006. Comparison of feeding guild structure and ecomorphology of intertidal fish assemblages from central California and central Chile. Marine Ecology Progress Series, 319: 65-84.

Conselho Estadual de Recursos Hídricos do Estado da Paraíba (CERH). 2004. Proposta de instituição do Comitê das Bacias Hidrográficas do Litoral Norte (CERHLN), João Pesssoa, PB conforme resolução $\mathrm{n}^{\circ} 1$, de 31 de agosto de 2003, do CERHPB. João Pessoa, PB. 
Chao, L. N. \& J. A. Musick. 1977. Life history, feeding habits, and functional morphology of juvenile Sciaenid fishes in the York River estuary, Virginia. Fishery Bulletin, 75: 657-702.

Chi-Espínola, A. A. \& M. E. Vega-Cendejas. 2013. Hábitos alimenticios de Sphoeroides testudineus (Perciformes:Tetraodontidae) en el sistema lagunar de Ría Lagartos, Yucatán, México. Revista de Biología Tropical, 61: 849-858.

Costa, C. \& S. Cataudella. 2007. Relationship between shape and trophic ecology of selected species of Sparids of the Caprolace coastal lagoon (Central Tyrrhenian sea). Environmental Biology of Fishes, 78: 115-123.

Douglas, M. E. \& W. J. Matthews. 1992. Does morphology predict ecology? Hypothesis testing within a freshwater stream fish assemblage. Oikos, 65: 213-224.

Dwyer, K. S., J. A. Brown, C. Parrish \& S. P. Lall. 2002. Feeding frequency affects food consumption, feeding pattern and growth of juvenile yellowtail flounder (Limanda ferruginea). Aquaculture, 213: 279-292.

Elliot, M., A. K. Whitfield, I. C. Potter, S. J. M. Blaber, D. P. Cyrus, F. G. Nordlie \& T. D. Harrison. 2007. The guild approach to categorizing estuarine fish assemblages: a global review. Fish and Fisheries, 8: 241-268.

Faye, D., F. Le Loc'h, O. T. Thiaw \& L. T. Morais. 2012. Mechanisms of food partitioning and ecomorphological correlates in ten fish species from a tropical estuarine marine protected area (Bamboung, Senegal, West Africa). African Journal of Agricultural Research, 7: 443-455.

Freitas, M. O., V. Abilhoa \& G. H. C. Silva. 2011. Feeding ecology of Lutjanus analis (Teleostei: Lutjanidae) from Abrolhos Bank, Eastern Brazil. Neotropical Ichthyology, 9: 411-418.

Gatz, A. J., Jr. 1979. Community organization in fishes as indicate by morphological features. Ecology, 60: 711-718.

Gibran, F. Z. 2010. Habitat partitioning, habits and convergence among coastal nektonic fish species from the São Sebastião Channel, southeastern Brazil. Neotropical Ichthyology, 8: 299-310.

Gomes, L. N., J. de R. Pinheiro-Júnior \& N. M. Piorski. 2003. Aspectos ecomorfológicos da comunidade de peixes do estuário do Rio Anil, Ilha de São Luís-MA. Boletim do Laboratório de Hidrobiologia, 16: 29-36.

Guedes, A. P. P. \& F. G. Araújo. 2008. Trophic resource partitioning among five flatfish species (Actinopterygii, Pleuronectiformes) in a tropical bay in south-eastern Brazil. Journal of Fish Biology, 72: 1035-1054.

Hammer, O., D. A. T. Harper \& P. D. Ryan. 2001. Past: Paleontological Statistics Software Package for Education and Data Analysis. Paleontologia Electronica, 4: 1-9.

Helfman, G. S., B. B. Collette, D. E. Facey \& B. W. Bowen. 2009. The diversity of fishes: Biology, Evolution, and Ecology. West Sussex, Wiley-Blackwell, 720p.

Herler, J. 2007. Microhabitats and ecomorphology of coral- and coral rock-associated gobiid fish (Teleostei: Gobiidae) in the northern Red Sea. Marine Ecology, 28(Suppl. 1): 82-94.

Hourston, M., M. E. Platell, F. J. Valesini \& I. C. Potter. 2004. Factors influencing the diets of four morphologically divergent fish species in nearshore marine waters. Journal of the Marine Biological Association of the United Kingdom, 84: 805-817.

Inoue, T., Y. Suda \& M. Sano. 2005. Food habits of fishes in the surf zone of a sandy beach at Sanrimatsubara, Fukuoka Prefecture, Japan. Ichthyological Research, 52: 9-14.
Keast, A. \& D. Webb. 1966. Mouth and body form relative to feeding ecology in the fish fauna of a small lake, Lake Opinicon, Ontario. Journal of the Fisheries Research Board of Canada, 23: 1845-1874.

Kotrschal, K. 1989.Trophic ecomorphology in eastern Pacific blennioid fishes: character transformation of oral jaws and associated change of their biological roles. Environmental Biology of Fishes, 24: 199-218.

Macedo, M. J. H., R. V. S. Guedes, F. A. S. Sousa \& F. R. C. Dantas. 2010. Análise do índice padronizado de precipitação para o estado da Paraíba, Brasil. Revista Ambiente \& Água, 5: 204-214.

Maes, J. \& F. Ollevier. 2002. Size structure and feeding dynamics in estuarine clupeoid fish schools: field evidence for the school trap hypothesis. Aquatic Living Resources, 15: 211-216.

Marsh, E. 1977. Structural modifications of the pectoral fin rays in the order Pleuronectiformes. Copeia, 3: 575-578.

Mazzoni, R., M. Moraes, C. F. Rezende \& J. C. Miranda. 2010. Alimentação e padrões ecomorfológicos das espécies de peixes de riacho do alto rio Tocantins, Goiás, Brasil. Iheringia. Série Zoologia, 100: 162-168.

Medeiros, P. R. \& R. T. C. Ramos. 2007. Predicting ecomorphological patterns from morphology of a tropical estuarine fish assemblage. Biociências, 15: 40-46.

Motta, P. J., K. B. Clifton, P. Hernandez \& B. T. Eggold. 1995. Ecomorphological correlates in ten species of subtropical seagrass fishes: diet and microhabitat utilization. Environmental Biology of Fishes, 44: 37-60.

Mourão, J. S. \& N. Nordi. 2003. Etnoictiologia de pescadores artesanais do estuário do Rio Mamanguape, Paraíba, Brasil. Boletim do Instituto de Pesca, 29: 9-17.

Moyle, P. B. \& J. J. Cech, Jr. 2004. Fishes: an introduction to Ichthyology. Benjamin Cummings; 5th ed. Upper Saddle River, NJ, Pearson Prentice Hall. 726p.

Norton, S. F., J. J. Luczkovich \& P. J. Motta. 1995. The role of ecomorphological studies in the comparative biology of fishes. Environmental Biology of Fishes, 44: 287-304.

Nybakken, J. W. \& M. D. Bertness. 2005. Marine biology: an ecological approach. 6th ed. San Francisco, Pearson/ Benjamin Cummings, 579p.

Oliveira, E. F., E. Goulart, L. Breda, C. V. Minte-Vera, L. R. S. Paiva \& M. R. Vismara. 2010. Ecomorphological patterns of the fish assemblage in a tropical floodplain: effects of trophic, spatial and phylogenetic structures. Neotropical Ichthyology, 8: $569-586$

Osório, F. M., W. O. Godinho \& T. M. C. Lotufo. 2011. Ictiofauna associada às raízes de mangue do estuário do Rio Pacoti CE, Brasil. Biota Neotropica, 11: 415-420.

Palmeira, L. P. \& C. Monteiro-Neto. 2010. Ecomorphology and food habits of teleost fishes Trachinotus carolinus (Teleostei: Carangidae) and Menticirrhus littoralis (Teleostei: Sciaenidae), inhabiting the surf zone of Niterói, Rio de Janeiro, Brazil. Brazilian Journal of Oceanography, 58(Special issue II CBBM): 1-9.

Paludo, D. \& V. S. Klonowski. 1999. Barra de Mamanguape PB: estudo do impacto do uso de madeira de manguezal pela população extrativista e da possibilidade de reflorestamento e manejo dos recursos madeireiros. São Paulo, Conselho Nacional da Reserva da Biosfera da Mata Atlântica. Série Cadernos da Reserva da Biosfera da Mata Atlântica. Série Recuperação, cad. n 16). $^{\circ}$ p. 
Peres-Neto, P. R. 2004. Patterns in the co-occurrence of fish species in streams: the role of site suitability, morphology and phylogeny versus species interactions. Oecologia, 140: 352-360.

Piet, G. J. 1998. Ecomorphology of a size structured tropical freshwater fish community. Environmental Biology of Fishes, 51: 67-86.

Piorski, N. M., J. R. L. Alves, M. R. B. Machado \& M. M. F. Correia. 2005. Alimentação e ecomorfologia de duas espécies de piranhas (Characiformes: Characidae) do lago de Viana, estado do Maranhão, Brasil. Acta Amazonica, 35: 63-70.

Piorski, N. M., E. C. S. Dourado \& J. L. S. Nunes. 2007. Análise ecomorfológica de três espécies de peixes do Parque Estadual Marinho do Parcel de Manuel Luiz, Nordeste do Brasil. Boletim do Laboratório de Hidrobiologia, 20: 69-76.

Rocha, M. S. P., J. S. Mourão, W. M. S. Souto, R. R. D. Barboza \& R. R. N. Alves. 2008. O uso dos recursos pesqueiros no estuário do Rio Mamanguape, estado da Paraíba, Brasil. Interciencia, 33: 903-909.

Sampaio, A. L. A. \& E. Goulart. 2011. Ciclídeos neotropicais: ecomorfologia trófica. Oecologia Australis, 15: 775-798.

Sampaio, A. L. A., J. P. A. Pagotto \& E. Goulart. 2013. Relationships between morphology, diet and spatial distribution: testing the effects of intra and interspecific morphological variations on the patterns of resource use in two Neotropical Cichlids. Neotropical Ichthyology, 11: 351-360.

Schaefer, K. M. 1992. An evaluation of geographic and annual variation in morfometric characters and gill-raker counts of yellowfin tuna, Thunnus albacares, from the Pacific Ocean. Inter-American Tropical Tuna Commission. Bulletin, 20: 135-163.

Schmitz, L. \& P. C. Wainwright. 2011. Ecomorphology of the eyes and skull in zooplanktivorous labrid fishes. Coral Reefs, 30: 415-428.

Teixeira, I. \& S. T. Bennemann. 2007. Ecomorfologia refletindo a dieta dos peixes em um reservatório no sul do Brasil. Biota Neotropica, 7: 67-76.

Valentin, J. L. 2000. Ecologia numérica: uma introdução à análise multivariada de dados ecológicos. Rio de Janeiro, Interciência, $117 \mathrm{p}$.
Vasconcelos Filho, A. L., D. A. N. Vieira, S. Neumann Leitão. 2011. Copepoda as food of young tropical estuarine fishes. Tropical Oceanography, 39: 133-141.

Volpedo, A. V., D. V. Fuchs. 2010. Ecomorphological patterns of the lapilli of Paranoplatense Siluriforms (South America). Fisheries Research, 102: 160-165.

Wainwright, P. C. \& B. A. Richard. 1995. Predicting patterns of prey use from morphology of fishes. Environmental Biology of Fishes, 44: 97-113.

Wainwright, P. C. \& D. R. Bellwood. 2002. Ecomorphology of feeding in coral reef fishes. Pp. 33-55. In: Sale, P. F. (Ed.). Coral reef fishes: dynamics and diversity in a complex ecosystem. Academic Press, San Diego, 549p.

Wainwright, P. C., S. H. Huskey, R. G. Turingan \& A. M. Carroll. 2006. Ontogeny of suction feeding capacity in snook, Centropomus undecimalis. Journal of Experimental Zoology, 305A: 246-252.

Watson, D. J. \& E. K. Balon. 1984. Ecomorphological analysis of fish taxocenes in rainforest streams of northern Borneo. Journal of Fish Biology, 25: 371-384.

Webb, P. W. 1984. Body form, locomotion and foraging in aquatic vertebrates. American Zoologist, 24: 107-120.

Webb, P. W. 2002. Kinematics of plaice, Pleuronectes platessa, and cod, Gadus morhua, swimming near the bottom. Journal of Experimental Biology, 205: 2125-2134.

Winemiller, K. O. 1991. Ecomorphological diversification in lowland freshwater fish assemblages from five biotic regions. Ecological Monographs, 61: 343-365.

Willis, S. C., K. O. Winemiller \& H. López-Fernadez. 2005. Habitat structural complexity and morphological diversity of fish assemblages in a Neotropical floodplain river. Oecologia, 142: 284-295.
Submitted June 4, 2014 Accepted January 29, 2015 by Norma Hahn Published June 30, 2015 
